OPEN ACCESS

Edited by:

Lisa Ann Tell,

University of California, Davis,

United States

Reviewed by:

Esteban Soto,

University of California, Davis,

United States

Fan Yang,

Henan University of Science and

Technology, China

*Correspondence:

Whitney Greene

wgreenedvm@gmail.com

${ }^{\dagger}$ Present address:

Natalie D. Mylniczenko,

Disney's Animals, Science, and Environment, Bay Lake, FL,

United States

FORCID:

Gregory A. Lewbart orcid.org/0000-0003-0716-1387

Specialty section

This article was submitted to Veterinary Pharmacology and Toxicology,

a section of the journal

Frontiers in Veterinary Science

Received: 20 July 2020

Accepted: 18 August 2020

Published: 07 October 2020

Citation:

Greene W, Mylniczenko ND, Storms T, Burns CM, Lewbart GA, Byrd $L$ and Papich MG (2020) Pharmacokinetics of Ketoprofen in Nile Tilapia (Oreochromis niloticus) and Rainbow Trout (Oncorhynchus mykiss). Front. Vet. Sci. 7:585324 doi: 10.3389/fvets.2020.585324

\section{Pharmacokinetics of Ketoprofen in Nile Tilapia (Oreochromis niloticus) and Rainbow Trout (Oncorhynchus mykiss)}

\author{
Whitney Greene ${ }^{1 *}$, Natalie D. Mylniczenko ${ }^{2 \dagger}$, Timothy Storms ${ }^{3}$, Charlene M. Burns ${ }^{1}$, \\ Gregory A. Lewbart ${ }^{4 \neq}$, Lynne Byrd ${ }^{1}$ and Mark G. Papich ${ }^{4}$
}

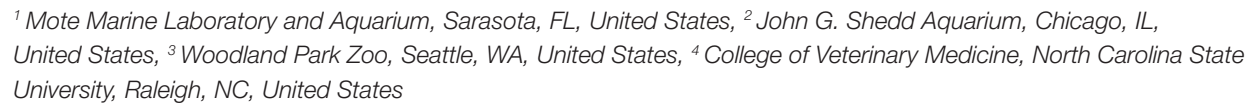

The objective of this study was to document the pharmacokinetics of ketoprofen following $3 \mathrm{mg} / \mathrm{kg}$ intramuscular (IM) and intravenous (IV) injections in rainbow trout (Oncorhynchus mykiss) and $8 \mathrm{mg} / \mathrm{kg}$ intramuscular (IM) injection in Nile tilapia (Oreochromis niloticus). Plasma was collected laterally from the tail vein for drug analysis at various time intervals up to $72 \mathrm{~h}$ following the injection of ketoprofen. In trout, area under the curve (AUC) levels were $115.24 \mu \mathrm{g} \mathrm{hr} / \mathrm{mL}$ for IM and $135.69 \mu \mathrm{g} \mathrm{hr} / \mathrm{mL}$ for IV groups with a half-life of 4.40 and $3.91 \mathrm{~h}$, respectively. In both trout and tilapia, there were detectable ketoprofen concentrations in most fish for $24 \mathrm{~h}$ post-injection. In tilapia, there was a large difference between the R- and S-enantiomers, suggesting either chiral inversion from R- to S-enantiomer or more rapid clearance of the R-enantiomer. AUC values of the S- and R-enantiomers were 510 and $194 \mu \mathrm{g} \mathrm{hr} / \mathrm{Ml}$, respectively, corresponding to a faster clearance for the R-enantiomer. This study shows that there were very high plasma concentrations of ketoprofen in trout and tilapia with no adverse effects observed. Future studies on the efficacy, frequency of dosing, analgesia, adverse effects, and route of administration are warranted.

\footnotetext{
Keywords: ketoprofen, teleost, tilapia, rainbow trout, pharmacokinctics, non-steroidal anti-inflammatory drugs (NSAIDs), Oncorhynchus mykiss, Oreochromis niloticus
}

\section{INTRODUCTION}

There is increasing awareness to the importance of animal welfare in teleost fish under human care, with particular attention to pain and inflammation management. Previously, references suggested that fish are incapable of feeling pain (1), but further research has elucidated that fish possess nociceptors which transmit painful stimuli and are similar to nociceptors found in mammals (2-6). Additionally, teleosts have been found to respond adversely to negative stimuli and such corresponding behavioral changes may indicate a response to pain (7-11). With this increased knowledge in teleost pain response, fish may benefit from medications that aid in reducing pain and inflammation (12-16). Two studies in the Netherlands support this claim and concluded that humane medical practice dictates the incorporation of appropriate analgesics into medical treatments and clinical procedures for fish $(17,18)$. 
Ketoprofen functions by inhibiting arachidonate cyclooxygenase (COX) enzymes, thereby reducing the production of thromboxanes and prostaglandins. Teleosts possess COX enzymes identical to those of mammals (18-20) and in mammals, the inhibition of these enzymes results in antiinflammatory, antipyretic, and analgesic properties. Therefore, fish should benefit from anti-inflammatory and analgesic drugs (21). Ketoprofen is a racemic mixture of R- and S- enantiomers $(22,23)$. Although the two enantiomers have the same chemical structure, they produce differences in pharmacology, toxicology, pharmacokinetics, and metabolism (24). In mammals, the $\mathrm{S}$-form is the most active for therapeutic effects (eutomer); however, it is unknown which enantiomer is the most active in ectotherms (24). In order to provide the needed analgesia and anti-inflammation, more information about how these medications influence teleosts is needed to establish dosages and treatment regimens.

There have been three studies examining analgesic effect of ketoprofen in fish but no pharmacokinetic data has been reported $(12,14,25)$. Pharmacokinetics have been reported for meloxicam in tilapia, but the half-life (IV $=1.36 \mathrm{~h}$ and $\mathrm{IM}=1.8 \mathrm{~h}$ ), and elimination time were both rapid compared to dogs (24h) (26), therefore a different drug in this species is warranted (27). Pharmacokinetic data for ketoprofen is essential to understand its disposition and to facilitate the design of dosing regimens. To this end, the objective of this study was to generate pharmacokinetic data for ketoprofen use in rainbow trout (Oncorhynchus mykiss) and Nile tilapia (Oreochromis niloticus). The intravenous route is recommended to generate pharmacokinetics in exotic species (28), however, intramuscular is often more practical clinically and less stressful to the animal. Ketoprofen was administered by injection, via intravenous (IV) and intramuscular (IM) in trout at $3 \mathrm{mg} / \mathrm{kg}$ body weight and via IM injection at $8 \mathrm{mg} / \mathrm{kg}$ in tilapia to establish pharmacokinetics.

\section{MATERIALS AND METHODS}

\section{Animal Husbandry (Trout)}

Twenty-four aquaculture-raised trout were included in the study, with an average weight of $819 \mathrm{~g}$ for the animals in the IV injection group and $775 \mathrm{~g}$ for the IM injection group. Animals were kept in individually labeled floating laundry baskets measuring $68 \times 47$ $\times 30 \mathrm{~cm}$ inside a larger tank for the study. Animals were allowed to acclimate for a minimum of 30 days prior to the initiation of the study. All individuals were determined to be clinically healthy based on behavior and body condition, with no visible signs of illness or disease. Water temperature was maintained at $15^{\circ} \mathrm{C}$ and water quality was kept within ranges considered appropriate for the species. The study was approved by the research committee at the John G. Shedd Aquarium, Chicago, Illinois.

\section{Animal Husbandry (Tilapia)}

Twelve Nile tilapia were collected from a larger population of fish that had no visible signs of illness and were determined to be clinically healthy based on behavior and body condition. The average weight for the fish was $733 \mathrm{~g}$. Animals were kept in individually labeled floating laundry baskets measuring $68 \times$
$47 \times 30 \mathrm{~cm}$ inside a larger 6,814 L fiberglass closed recirculating tank for the study. Animals were acclimated for $36 \mathrm{~h}$ prior to the initiation of the study. Water was maintained at $28^{\circ} \mathrm{C}$ and all water quality parameters were kept within ranges appropriate for the species. The study was approved by Mote Marine Laboratory's Institutional Animal Care and Use Committee (IACUC).

\section{Sample Collection (Trout)}

Twenty-four trout were divided into two groups of 12 animals each; at each session, animals were gently moved into a net from the basket and anesthetized with tricaine methanesulfonate (MS-222; Argent Chemical Laboratories, Redmond, WA 98052, USA) at $100 \mathrm{mg} / \mathrm{L}$ concentration, procedures usually lasted 35 min. Each group of 12 animals received an IV or IM injection of ketoprofen (Ketofen $100 \mathrm{mg} / \mathrm{ml}$ injectable solution, Zoetis Inc., Kalamazoo, MI 49007, USA) at $3 \mathrm{mg} / \mathrm{kg}$. This dosage was determined from an initial study looking at analgesia and minimum gill concentration (MGC) with MS-222 and ketoprofen with dosages tested from 1 to $5 \mathrm{mg} / \mathrm{kg}$ in $1 \mathrm{mg} / \mathrm{kg}$ increments (14).

Blood samples $(0.5-1.0 \mathrm{~mL})$ were collected from the caudal tail vein using 22-ga needles attached to 3 -mL syringes and placed in lithium heparin (Li-heparin) microtainers. Six animals in each injection group had samples of blood collected at: $0,0.5,3,12$, 48 , and $96 \mathrm{~h}$, while the other six fish were sampled at: $0,1.5,6$, 24 , and $72 \mathrm{~h}$. All blood samples were centrifuged within $30 \mathrm{~min}$ after each collection at 700 relative centrifugal field (RCF) for $15 \mathrm{~min}$. Plasma was then collected via pipette from each sample and stored in cryovials at $-80^{\circ} \mathrm{C}$ until analysis. Animals were returned to the animal collection after the study, with no negative side effects identified.

\section{Sample Collection (Tilapia)}

All 12 tilapia were administered a single IM injection of ketoprofen (Ketofen $100 \mathrm{mg} / \mathrm{ml}$ injectable solution, Zoetis Inc., Kalamazoo, MI 49007, USA) at $8 \mathrm{mg} / \mathrm{kg}$ without anesthesia. Animals were moved into a net from the basket, wrapped in a chamois cloth, and venipuncture performed all within $60 \mathrm{~s}$. On rare occasions a second attempt required, this extended the handling time an additional 15-30 s. The above dosage was based on results from a pilot study in spadefish (Chaetodipterus faber) at dosages of $1,2,4$, and $8 \mathrm{mg} / \mathrm{kg} \mathrm{IM}$, and the above mentioned trout pilot study (14). Blood samples $(0.5-1.0 \mathrm{~mL})$ were collected from the caudal tail vein using 22-ga needles attached to 3-mL syringes by a trained aquatic animal veterinary technician to minimize handling time and stress at varying time points $(0,0.5,1,2,4$, $8,12,24 \mathrm{~h}$ ) and placed in $1.3 \mathrm{ml}$ lithium heparin (Li-heparin) microtainers. Some minor skin darkening was observed around the injection site in 2 of the 12 animals sampled, but this resolved after the $1 \mathrm{~h}$ sampling point.

All blood samples were centrifuged within $15 \mathrm{~min}$ after each collection at $1372 \mathrm{RCF}$ for $5 \mathrm{~min}$. Plasma was then collected via pipette from each sample and banked in cryovials at $-80^{\circ} \mathrm{C}$ until analysis. Following the final sample collection, all fish were humanely euthanized using MS-222 (Syndel, Ferndale, WA 98248, USA) at $750 \mathrm{ppm}$ for $30 \mathrm{~min}$ followed by severing of the spinal cord. 


\section{Sample Processing and Analysis (Trout)}

Plasma samples were analyzed using a reverse phase highperformance liquid chromatography method. The system consisted of a 2,690 separations module, a 2,487 absorbance detector, and a computer equipped with Empower software. Ketoprofen was extracted from plasma samples using liquid extraction. Previously frozen samples were briefly thawed and vortexed. One milliliter of plasma was transferred to a clean screw-top test tube followed by $75 \mu \mathrm{L}$ internal standard $(5.0 \mu \mathrm{g} / \mathrm{mL}$ phenacetin). One hundred microliters of $3 \%$ formic acid was added followed by $6 \mathrm{~mL}$ of chloroform: IPA (80:20) and the tubes were rocked for $15 \mathrm{~min}$ and then centrifuged for $15 \mathrm{~min}$ at $1,000 \times \mathrm{g}$. The resulting layer was transferred to a clean tube and evaporated to dryness with nitrogen gas.

The compounds were separated on a Symmetry Shield RP $18(3.9 \times 150 \mathrm{~mm}, 5 \mu \mathrm{m})$ column with a Symmetry Shield RP 18 guard column (Waters Corporation, Milford, MA 01757, USA). The mobile phase was an isocratic mixture of (A) $20 \mathrm{mM}$ potassium dihydrogen phosphate adjusted to $\mathrm{pH} 3.0$ and (B) methanol (50:50). The flow rate was $1 \mathrm{~mL} / \mathrm{min}$ and the column temperature was ambient. Absorbance was measured at $258 \mathrm{~nm}$.

Standard curves for plasma analysis were prepared by fortifying untreated, pooled plasma with ketoprofen to produce a linear concentration range of $10-15,00 \mathrm{ng} / \mathrm{mL}$. Calibration samples were prepared exactly as plasma samples. Average recovery for ketoprofen was $95 \%$ while intra- and inter-assay variability were below $10 \%$. The lower limit of quantification was $10 \mathrm{ng} / \mathrm{mL}$.

\section{Sample Processing and Analysis (Tilapia)}

In this study, a selective chiral assay was used to distinguish between the R- and S-isomer of ketoprofen in tilapia; when the study with rainbow trout was conducted, a chiral assay was not available. A validated assay from a previous study was performed (29) for the drug analysis of the R- and S- enantiomers of ketoprofen. Drug concentrations were determined using a high-pressure liquid chromatography (HPLC) chiral assay that separates the R- and S-enantiomers of ketoprofen. The assay for this study was validated by analyzing blank plasma from untreated fish that was fortified with concentrations of a ketoprofen reference standard. The method was accepted for this study after it was confirmed that it met acceptance criteria from the earlier study.

\section{Pharmacokinetic Analysis}

A population pharmacokinetic approach with non-linear mixedeffects modeling was used for the trout (Phoenix ${ }^{\circledR}, \mathrm{NLME}^{\mathrm{TM}}$, version 8.4, Certara, Princeton, NJ 08540, USA). This design does not allow individual pharmacokinetics parameters calculated for each animal, but it generates values for fixed effects and random effects for the population. A naive averaged data approach was used to obtain initial estimates (data not shown). From these initial estimates, and using a single bolus input, a non-linear mixed effects (NLME) model was fitted to these data. Compartmental analysis of the data from the ketoprofen concentrations in trout was calculated using a 1compartment model with first-order input. The model calculated the primary parameters of elimination rate constant $(\mathrm{Ke})$ and volume of distribution (V). Secondary parameters calculated include the half-life, area-under-the-curve (AUC), and peak concentration ( $\mathrm{C}_{\mathrm{MAX}}$ ).

Pharmacokinetic analysis for ketoprofen administered to tilapia was performed, for each enantiomer, using a onecompartment pharmacokinetic model, with first-order input and elimination (WinNonlin ${ }^{\mathrm{TM}}$, Phoenix ${ }^{\circledR}$, version 8.4, Certara, Princeton, NJ 08540, USA). A simple, one-compartment model provided the best fit to the data after analyzing diagnostic plots and goodness-of-fit criteria. The pharmacokinetic results were averaged for all fish using a standard two-stage (STS) approach.

Various models were tested with different error structures to determine the best-fit base model. The models were parameterized using the simplest model that provided acceptable goodness of fit plots, diagnostic plots of residuals, and scatter plots of predicted vs. observed values. Interindividual (between-subject) variability were expressed using an exponential error model. The values calculated included a typical value (theta, or fixed effect) for the population estimate of the parameter of interest, and random effect for the inter-individual differences of the parameter of interest. An error value was included for the residual intra-subject variability.

\section{RESULTS}

The pharmacokinetic curves for the $3 \mathrm{mg} / \mathrm{kg}$ ketoprofen injections in trout are presented in Figure 1, with panels A-D representing the two routes of administration (IM and IV), with spaghetti plots of individual fish (panels A and B) and the data fitted to the population model (panels $C$ and D). The spaghetti plots show the variation among individuals and the final model for the population.

Table 1 shows the pharmacokinetic parameters for the population model of ketoprofen in trout after IM and IV injection of $3 \mathrm{mg} / \mathrm{kg}$. Despite different routes of administration, the half-life was similar. The injection from the IM administration was almost complete as estimated from the AUC ratio of IM/IV (85\% absorption) and peak concentration of 18.15 and $24.07 \mu \mathrm{g} / \mathrm{mL}$ from IM and IV injection, respectively. The inter-individual (between-subject) variability in concentrations from the IM injection seen in Figure 1A, is likely caused by variable IM absorption among fish, but difference in clearance cannot be excluded.

The plasma concentrations for each enantiomer (R- and S-) after ketoprofen injection in tilapia are shown in Figure 2. Pharmacokinetic parameters for the $8 \mathrm{mg} / \mathrm{kg}$ IM ketoprofen administration to tilapia are presented in Table 2. There was a large difference between the R- and S-enantiomers, as seen by differences in the area-under-the-curve (AUC) and peak concentration $\left(\mathrm{C}_{\mathrm{MAX}}\right)$. The results showed a rapid absorption, but with elimination differences between the $\mathrm{R}$ - and Senantiomer (Table 2). There were detectable concentrations in most fish for $24 \mathrm{~h}$ post injection (Figure 2). No adverse effects were observed other than some minor skin darkening around the 




FIGURE 1 | Ketoprofen concentrations in trout after IM and IV administration at $3 \mathrm{mg} / \mathrm{kg}$. (A,B) shows the spaghetti plots of individual fish for IM, and IV administration, respectively, with actual points (open circles) and fitted lines (solid lines). (A,B) shows individual subjects fitted to the population pharmacokinetic model. Plots in (C,D), (IM and IV administration, respectively) shows the fitted model for the population using a one compartment model with first order absorption, when inter-individual variability is accounted for in the model. Note the improvement in fit using the population model approach in (C,D), compared to individual plots in (A,B).

injection site in 2 of the 12 tilapia sampled, and this resolved after the $1 \mathrm{hr}$ sampling point.

\section{DISCUSSION}

This is the first reported analysis of the pharmacokinetics of the NSAID ketoprofen in teleost fish. Ketoprofen has been assessed as an analgesic in some fish $(12,14,25)$. A minimum gill concentration model (akin to minimum alveolar concentration in traditional mammalian anesthesia studies) was established in rainbow trout (Oncorhynchus mykiss), with a noxious stimulus applied under varying dosages of butorphanol and ketoprofen against varying concentrations of MS-222 (14). The same model was used in the chain dogfish (Scyliorhinus retifer) (with a change of terminology from MGC to minimum anesthetic concentration
(MAC) but this approach did not show a change in MAC to any ketoprofen or MS-222 dosage used (25). A similar MAC response model was also assessed in goldfish using a ketoprofen dosage of $0.5-2 \mathrm{mg} / \mathrm{kg}$ IM and in this case, the drug was found to significantly decrease the MAC (16). Another study showed that ketoprofen at $2 \mathrm{mg} / \mathrm{kg}$ reduced muscle damage post-surgery in koi (12). No adverse effects were reported in any of these studies. Interestingly, when comparing the risks of ketoprofen and diclofenac in rainbow trout, ketoprofen was determined to be the safer of the two drugs, as diclofenac alters organ histology and gene expression in fish at $1 \mu \mathrm{g} / \mathrm{L}(30)$.

Ketoprofen is formulated as a racemic mixture, containing equal (50:50) amounts of each R- and S- enantiomers (23). Understanding the pharmacokinetics of each enantiomer can provide information about whether potential therapeutic efficacy 
and/or toxic effects can be attributed to one enantiomer over the other $(22,23,31)$. The S-enantiomer of ketoprofen is associated with anti-prostaglandin activity and toxicity, while the R-enantiomer is associated with analgesia and has no interaction with the COX binding site (32). Additionally, the S-enantiomer is absorbed rapidly from the gastrointestinal tract and is characterized by a quick onset of biological action (33). In the present study, exposure was much greater for the S-enantiomer in teleosts compared to the R-, which is similar to findings in studies with horses, dogs, and cats $(31,32,34-37)$. R- and S-enantiomers were analyzed separately in the present study for tilapia but they were not differentiated for trout. It is unknown which form is the

TABLE 1 | Population pharmacokinetic data for ketoprofen injected in trout at a dose of $3 \mathrm{mg} / \mathrm{kg}$, IV or IM.

\begin{tabular}{|c|c|c|c|c|c|}
\hline \multicolumn{3}{|c|}{ IM route $3 \mathrm{mg} / \mathrm{kg}$} & \multicolumn{3}{|c|}{$\mathrm{IV}$ route $3 \mathrm{mg} / \mathrm{kg}$} \\
\hline Parameter & Units & Estimate & Parameter & Units & Estimate \\
\hline$\theta \mathrm{V}$ & $\mathrm{L} / \mathrm{kg}$ & 0.17 & $\theta \mathrm{V}$ & $\mathrm{L} / \mathrm{kg}$ & 0.12 \\
\hline$\theta \mathrm{Ke}$ & $1 / \mathrm{hr}$ & 0.16 & $\theta \mathrm{Ke}$ & $1 / \mathrm{hr}$ & 0.18 \\
\hline AUC & $\mu g^{*} h r / m L$ & 115.24 & AUC & $\mu g^{\star} h r / m L$ & 135.69 \\
\hline $\mathrm{C}_{\text {MAX }}$ & $\mu \mathrm{g} / \mathrm{mL}$ & 18.15 & $\mathrm{C}_{0}$ & $\mu \mathrm{g} / \mathrm{mL}$ & 24.07 \\
\hline $\mathrm{Cl} / \mathrm{F}$ & $\mathrm{mL} / \mathrm{hr} / \mathrm{kg}$ & 26.03 & $\mathrm{Cl} / \mathrm{F}$ & $\mathrm{mL} / \mathrm{hr} / \mathrm{kg}$ & 22.11 \\
\hline MRT & $\mathrm{hr}$ & 6.35 & MRT & $\mathrm{hr}$ & 5.64 \\
\hline Half-life & $\mathrm{hr}$ & 4.40 & Half-life & $\mathrm{hr}$ & 3.91 \\
\hline
\end{tabular}

The population pharmacokinetic model used non-linear mixed effects modeling (NLME) with a one-compartment, first order model. $\theta$ V is the true value (theta, fixed effect) volume of distribution; $\theta K e$ is the true value (theta, fixed effect) for the elimination rate constant. AUC is the area-under-the-curve for plasma concentration vs. time. $C_{\text {MAX }}$ is the peak concentration (IM), or $C_{0}$, the initial concentration (IV). CL, systemic clearance, or CL/F (per fraction absorbed for the IM administration. MRT, mean residence time. most active in teleosts but it has been found the S-enantiomer is the most active for therapeutic effects in mammals (2224, 39). One study assessed both enantiomers in freshwater fish (Alburnus alburnus, Lepomis gibbosus, Micropterus salmoides, Oncorhynchus mykiss, and Cyprinus carpio) and found no statistically significant difference in their concentration present in fish tissue (38). In this study, the volume of distribution was similar between both isomers.

For trout, the half-life of ketoprofen fell in-between the values reported for both the R- and S- in the tilapia, therefore, it may represent a contribution from both enantiomers. The clearance was similar between trout and tilapia, but the volume of distribution was lower in the tilapia. A relevant study in freshwater fish hepatic cell-lines found that the racemic mixture and the S-enantiomer may have acted through different mechanisms within cells and resulted in different responses (40). In the present study, the differences observed between the Rand $\mathrm{S}$-enantiomers represents either more rapid clearance of the $\mathrm{R}$-enantiomer, or chiral inversion from R- to the S-enantiomer, which occurs in mammals $(22,23,41,42)$.

There were some limitations to this study that are important to address. Necessary, repeat handling of animals is atypical when compared to other fish pharmacological studies. However, the origin and disposition of the animals in the present study were unique and intended for animals in aquaria where individuals are managed vs. a school. Additionally, repeat sampling is typical of similar studies in different taxa. MS222 was used as an anesthetic in trout, but not tilapia. With a fixed number of animals available and their welfare in mind, handling was designed to acquire samples with the least amount of anticipated stress for each species and their perceived levels of tolerance to restraint stress. The use of anesthetics has been shown to reduce stress in teleosts

\section{Ketoprofen Concentrations}

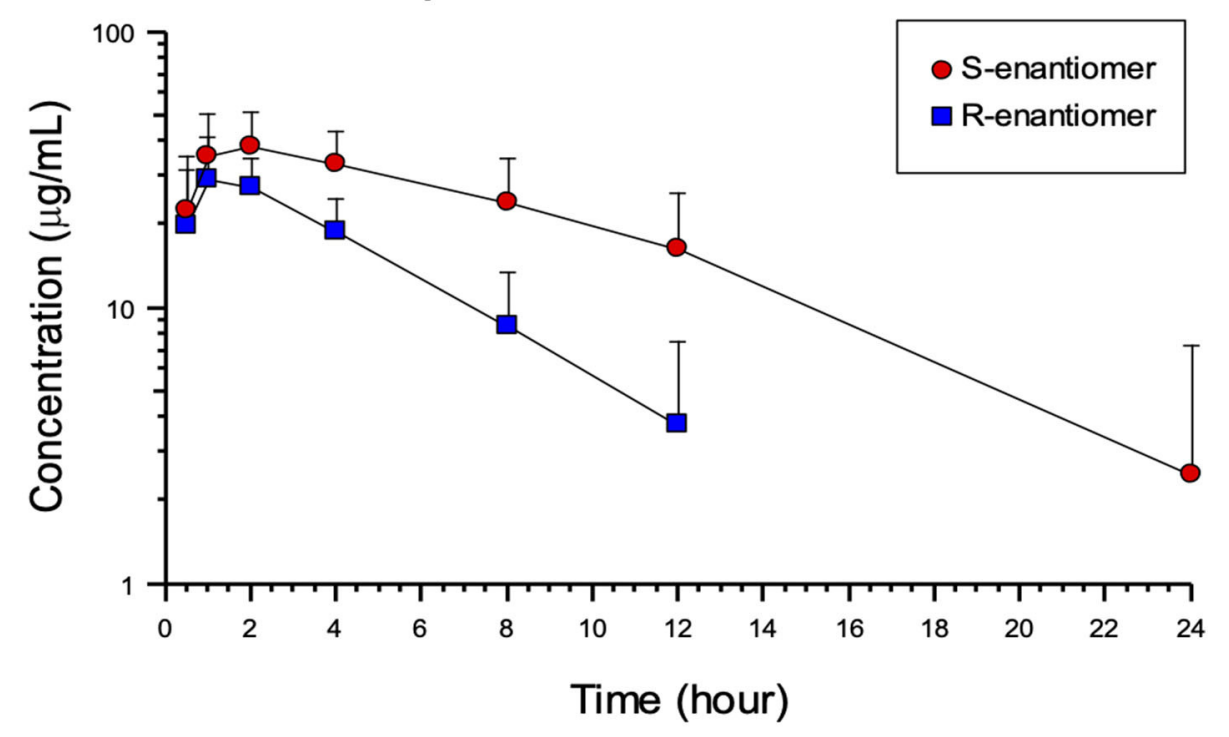

FIGURE 2 | Pharmacokinetic for S and R enantiomers after an 8 mg/kg ketoprofen intramuscular (IM) injection in Nile tilapia (Oreochromis niloticus). 
TABLE 2 | Summarized data after an $8 \mathrm{mg} / \mathrm{kg}$ intramuscular (IM) injection in Nile tilapia (Oreochromis niloticus).

\begin{tabular}{|c|c|c|c|c|}
\hline \multicolumn{5}{|c|}{ R-Enantiomer } \\
\hline Parameter & Units & Mean & Std.Dev. & CV\% \\
\hline AUC & $\mathrm{hr}^{*} \mu \mathrm{g} / \mathrm{mL}$ & 193.62 & 82.72 & 42.72 \\
\hline Clearance & $\mathrm{mL} / \mathrm{hr} / \mathrm{kg}$ & 24.41 & 11.96 & 48.99 \\
\hline Cmax & $\mu \mathrm{g} / \mathrm{mL}$ & 30.23 & 10.52 & 34.79 \\
\hline K01 & $1 / \mathrm{hr}$ & 1.80 & 1.79 & 99.14 \\
\hline Absorption half-life & $\mathrm{hr}$ & 0.64 & 0.44 & 68.14 \\
\hline K10 & $1 / \mathrm{hr}$ & 0.28 & 0.14 & 50.30 \\
\hline Elimination half-life & $\mathrm{hr}$ & 3.10 & 1.47 & 47.32 \\
\hline Tmax & $\mathrm{hr}$ & 1.60 & 0.55 & 34.64 \\
\hline $\mathrm{VD} / \mathrm{F}$ & $\mathrm{mL} / \mathrm{kg}$ & 98.11 & 41.01 & 41.80 \\
\hline \multicolumn{5}{|c|}{ S-Enantiomer } \\
\hline Parameter & Units & Mean & Std.Dev. & CV\% \\
\hline AUC & $\mathrm{hr}^{\star} \mu \mathrm{g} / \mathrm{mL}$ & 510.37 & 284.54 & 55.75 \\
\hline Clearance & $\mathrm{mL} / \mathrm{hr} / \mathrm{kg}$ & 10.29 & 6.44 & 62.57 \\
\hline Cmax & $\mu \mathrm{g} / \mathrm{mL}$ & 40.83 & 13.36 & 32.72 \\
\hline K01 & $1 / \mathrm{hr}$ & 4.80 & 8.89 & 185.08 \\
\hline Absorption half-life & $\mathrm{hr}$ & 0.82 & 0.74 & 90.41 \\
\hline K10 & $1 / \mathrm{hr}$ & 0.15 & 0.10 & 65.97 \\
\hline Elimination half-life & $\mathrm{hr}$ & 6.81 & 4.37 & 64.09 \\
\hline Tmax & $\mathrm{hr}$ & 2.13 & 1.14 & 53.56 \\
\hline VD/F & $\mathrm{mL} / \mathrm{kg}$ & 80.16 & 36.31 & 45.30 \\
\hline
\end{tabular}

(43-45), although responses are varied and contingent on species and circumstance $(46,47)$. While MS222 can induce cortisol release and alter some other biochemical values in trout (47-50), it has been shown that it reduces the stress response overall (45). Others may argue that anesthesia is stressful to the animal and could result in subsequent physiological effects (51). Thus, when handling time is minimal and procedures are minimally or noninvasive, the addition of anesthesia and increased total time of handling may not be needed (52). Tilapia have also been shown to respond more slowly to MS222 (53) and require high levels of sedation (54). Author personal experience (Burns, Mylniczenko) noted that the time and relatively high dose of MS222 required for this species for adequate anesthetic induction would be greater than the handling time required for sample collection and in that regard, was considered less beneficial to reduce stress. Additionally, handling techniques with skilled personnel were ensured to be rapid and without trauma. Thus, the use of anesthesia for handling in minimally invasive procedures in teleosts is a continued debate and needs to be assessed on a case by case basis considering staff experience, facility capacity, and species tolerance (46). Ideally, pharmacokinetic studies in fish should explore both manual restraint vs. anesthesia, as well as animal stress levels to fully understand the impact on drug kinetics. Finally, between subject variability was observed in the present study as has been seen in other studies $(47,55)$. Fluid shifts from the secondary vascular system and stress (56) could account for this variability but were out of the scope to explore for the current project and warrant future investigation.
The results from the present study provide pharmacokinetic data for ketoprofen at a dosage of 3 and $8 \mathrm{mg} / \mathrm{kg}$ in two teleost species. There were only minor adverse effects observed and no major effects at either dosage in any of the fish. Humane veterinary practice dictates the incorporation of appropriate analgesics and anti-inflammatories into medical treatment strategies for fish $(14,17,18)$. Though it cannot be inferred that these doses provided analgesia, they did reach what would be therapeutic levels in mammals. Additionally, at once-daily dosing the drug remained in the body for at least $24 \mathrm{~h}$ post injection in most fish, which makes it reasonable for clinical use in fish medicine.

\section{DATA AVAILABILITY STATEMENT}

All datasets generated for this study are included in the article/supplementary material.

\section{ETHICS STATEMENT}

The animal study was reviewed and approved by Mote Marine Laboratory and Aquarium Institutional Animal Care and Use Committee (IACUC).

\section{AUTHOR CONTRIBUTIONS}

WG: project design, development, sample collection (tilapia), and manuscript writing. NM: project design, development, sample collection (trout), and manuscript writing and mentoring. TS: project design, development, sample collection (trout), and manuscript writing. CB: project design, sample collection (tilapia), and manuscript writing. GL: project development (tilapia), mentoring, and manuscript writing. LB: sample collection and processing (tilapia). MP: sample analysis, pharmacokinetics, and manuscript writing. All authors contributed to the article and approved the submitted version.

\section{FUNDING}

Funding for trout pharmacokinetics from Morris Animal Foundation D03ZO-117, original project: Pharmacokinetics and Analgesic Effect of Butorphanol and Ketoprofen in Rainbow Trout (Oncorhynchus mykiss). Funding for the pharmacokinetics for tilapia from the Mote Marine Laboratory Scientific Fund.

\section{ACKNOWLEDGMENTS}

The authors thank Delta R. Dise of the Clinical Pharmacology at North Carolina State University and Sherry Cox from the University of Tennessee College of Veterinary Medicine for their assistance with ketoprofen analysis. John G. Shedd Aquarium: the dedicated Animal Health Technicians as well as Michael O'Neill, Jeff Boehm, and Lydia Staggs. Mote Marine Laboratory and Aquarium: Courtney Hessell, Weston Spoon, Brian Siegel, Matt Seguin, and Rachel Ayala. 


\section{REFERENCES}

1. Rose JD. The neurobehavioral nature of fishes and the question of awareness and pain. Rev Fisheries Sci. (2002) 10:1-38. doi: 10.1080/20026491051668

2. Ashley PJ, Sneddon LU, McCrohan CR. Nociception in fish: stimulus-response properties of receptors on the head of trout Oncorhynchus mykiss. Brain Res. (2007) 1166:47-54. doi: 10.1016/j.brainres.2007.07.011

3. Sneddon LU, Braithwaite VA, Gentle MJ. Do fishes have nociceptors? Evidence for the evolution of a vertebrate sensory system. Proc Roy Soc Lond Biol Sci. (2003) 270:1115-21. doi: 10.1098/rspb.2003.2349

4. Sneddon LU. Clinical anesthesia and analgesia in fish. J Exot Pet Med. (2012) 21:32-43. doi: 10.1053/j.jepm.2011.11.009

5. Sneddon LU, Wolfenden DCC, Leach MC, Valentim AM, Steenbergen PJ, Bardine B, et al. Ample evidence for fish sentience and pain. Anim Sentience. (2018) 162:1-8.

6. Woodruff ML. Pain in fish: evidence from peripheral nociceptors to pallial processing. Anim Sentience. (2018) 21:1-4.

7. Dunlop R, Millsopp S, Laming P. Avoidance learning in goldfish (Carassius auratus) and trout (Oncorhynchus mykiss) and implications for pain perception. Appl Anim Behav Sci. (2006) 97:255-71. doi: 10.1016/j.applanim.2005.06.018

8. Millsopp S, Laming P. Trade-offs between feeding and shock avoidance in goldfish (Carassius auratus). Appl Anim Behav Sci. (2008) 113:247-54. doi: 10.1016/j.applanim.2007.11.004

9. Ng TB, Chan STH. Adrenocorticotropin-like and opiate-like materials in the brain of the red grouper (Epinephelus akaara). Comp Biochem Physiol. (1990) 95C:159-62. doi: 10.1016/0742-8413(90)90098-T

10. Reilly SC, Quinn JP, Cossins AR, Sneddon LU. Behavioural analysis of a nociceptive event in fish: comparisons between three species demonstrate specific responses. Appl Anim Behav Sci. (2008) 114:248-59. doi: 10.1016/j.applanim.2008.01.016

11. Roques JAC, Abbink W, Geurds F, van de Vis H, Flik G. Tailfin clipping, a painful procedure: studies on Nile tilapia and common carp. Physiol Behav. (2010) 101:533-40. doi: 10.1016/j.physbeh.2010.08.001

12. Harms CA, Lewbart GA, Swanson CR, Kishimori JM, Boylan SM. Behavioral and clinical pathology changes in koi carp (Cyprinus carpio) subjected to anesthesia and surgery with and without intra-operative analgesics. Comp Med. (2005) 55:221-6.

13. Mettam JJ, Oulton LJ, McCrohan CR, Sneddon LU. The efficacy of three types of analgesic drugs in reducing pain in the rainbow trout, Oncorhynchus mykiss. Appl Anim Behav Sci. (2011) 133:265-74. doi: 10.1016/j.applanim.2011.06.009

14. Storms TN, Mylniczenko ND. Pain and analgesia in fish: unanswered question. In: Proceedings From the American Association of Zoo Veterinarians (AAZV) Annual Conference. San Diego, CA (2004).

15. Rizzo AL, Wooster GA, Guanzini LE, Peterson CM, Fenderson KS, Erb $\mathrm{HN}$, et al. Biochemical, histopathologic, physiologic, and behavioral effects of nonsteroidal antiinflammatory drugs in rainbow trout (Oncorhynchus mykiss). Comp Med. (2017) 67:106-11.

16. Ward JL, McCartney SP, Chinnadurai SK, Posner LP. Development of a minimum-anesthetic-concentration depression model to study the effects of various analgesics in goldfish (Carassius auratus). J Zoo Wildl Med. (2012) 43:214-22. doi: 10.1638/2010-0088.1

17. Lambooij E, van de vis $H$, Kloosternoer RJ, Pieterse C. Welfare aspects of live chilling and freezing of farmed eel (Anguilla anguilla): neurological and behavioural assessments. Aquaculture. (2002) 210:159-69. doi: 10.1016/S0044-8486(02)00050-9

18. Prescott SM, Yost HJ. The COXes of Danio: from mechanistic model to experimental therapeutics. Proc Natl Acad Sci USA. (2002) 99:9084-6. doi: 10.1073/pnas.152280699

19. Grosser T, Yusuff S, Cheskis E, Pack MA, Fitzgerald GA. Developmental expression of functional cyclooxygenases in zebrafish. Proc Natl Acad Sci USA. (2002) 99:8418-23. doi: 10.1073/pnas.112217799

20. Zou J, Neumann NF, Holland JW, Belosevic M, Cunningham C, Secombes CJ, et al. Fish macrophages express a cyclo-oxygenase- 2 homologue after activation. Biochem J. (1999) 340:153-9. doi: 10.1042/bj3400153

21. Chatigny F, Creighton CM, Stevens ED. Updated review of fish analgesia. $J$ Am Assoc Lab Anim Sci. (2018) 57:5-12.
22. Landoni MF, Soraci AL, Delatour P, Lees P. Enantioselective behaviour of drugs used in domestic animals: a review. J Vet Pharmacol Ther. (1997) 20:1-6. doi: 10.1046/j.1365-2885.1997.00045.x

23. Landoni MF, Soraci A. Pharmacology of chiral compounds 2arylpropionic acid derivatives. Curr Drug Metab. (2001) 2:37-51. doi: 10.2174/1389200013338810

24. Nguyen LA, He H, Pham-Huy C. Chiral drugs: an overview. Int J Biomed Sci. (2006) 2:85-100.

25. Davis MR, Mylniczenko N, Storms T, Raymond F, Dunn JL. Evaluation of intramuscular ketoprofen and butorphanol as analgesics in chain dogfish (Scyliorhinus retifer). Zoo Biol. (2006) 25:491-500. doi: 10.1002/zoo.20105

26. Khan SA, McLean MK. Toxicology of frequently encountered nonsteroidal anti-inflammatory drugs in dogs and cats. Vet Clin North Am Small Anim Pract. (2012) 42:289-306. doi: 10.1016/j.cvsm.2012.01.003

27. Fredholm DV, Mylniczenko N, Kukanich B. Pharmacokinetic evaluation of meloxicam after intravenous and intramuscular administration in nile tilapia (Oreochromis niloticus). J Zoo Wildl Med. (2016) 47:736-42. doi: 10.1638/2015-0253.1

28. Riviere JE. Basic principles and techniques of pharmacokinetic modeling. $J$ Zoo Wildl Med. (1997) 28:3-19.

29. Thompson KA, Papich MG, Higgins B, Flanagan J, Christiansen EF, Harms CA. Ketoprofen pharmacokinetics of R- and S-isomers in juvenile loggerhead sea turtles (Caretta caretta) after single intravenous and single- and multidose intramuscular administration. J Vet Pharmacol Ther. (2017) 41:340-8. doi: $10.1111 /$ jvp.12460

30. Cuklev F, Fick J, Cvijovic M, Kristiansson E, Forlin L, Larsson DGJ. Does ketoprofen or diclofenac pose the lowest risk to fish? J Hazard Mater. (2012) 229-230:100-6. doi: 10.1016/j.jhazmat.2012.05.077

31. Serrano-Rodriguez JM, Serrano JM, Rodriguez JM, Machuca MM, Gomez-Villamandos RJ, Navarrete-Calvo R. Pharmacokinetics of the individual enantiomer $\mathrm{S}-(+)$-ketoprofen after intravenous and oral administration in dogs at two dose levels. Res Vet Sci. (2014) 96:523-5. doi: 10.1016/j.rvsc.2014.03.021

32. Evans AM. Enantioselective pharmacodynamics and pharmacokinetics of chiral non- steroidal anti-inflammatory drugs. Eur J Clin Pharmacol. (1992) 42:237-56. doi: 10.1007/BF00266343

33. Barden J, Derry S, McQuay HJ, Moore RA. Single dose oral ketoprofen and dexketoprofen for acute postoperative pain in adults. Cochrane Database Syst Rev. (2008) 5:CD007355. doi: 10.1002/14651858.CD007355

34. Arifah AK, Landoni MF, Frean SP, Lees P. Pharmacodynamics and pharmacokinetics of ketoprofen enantiomers in sheep. Am J Vet Res. (2001) 62:77-86. doi: 10.2460/ajvr.2001.62.77

35. Knych HK, Arthur RM, Steinmetz S, McKemic DS. Pharmacokinetics of ketoprofen enantiomers following intravenous and oral administration to exercised thoroughbred horses. Vet J. (2016) 207:196-8. doi: 10.1016/j.tvjl.2015.09.018

36. Landoni MF, Comas W, Mucci N, Anglarilli G, Bidal D, Lees P. Enantiospecific pharmacokinetics and pharmacodynamics of ketoprofen in sheep. J Vet Pharmacol Ther. (1999) 22:349-59. doi: 10.1046/j.1365-2885.1999.00209.x

37. Lees P, Taylor PM, Landoni FM, Arifah AK, Waters C. Ketoprofen in the cat: pharmacodynamics and chiral pharmacokinetics. Vet J. (2003) 165:21-35. doi: 10.1016/S1090-0233(02)00168-5

38. Caballo C, Sicilla MD, Rubio S. Enantioselective analysis of non-steroidal anti-inflammatory drugs in freshwater fish based on microextraction with a supramolecular liquid and chiral liquid chromatographytandem mass spectrometry. Anal Bioanal Chem. (2015) 407:4721-31. doi: 10.1007/s00216-015-8675-5

39. Landoni MF, Lees P. Pharmacokinetics and pharmacodynamics of ketoprofen enantiomers in the horse. J Vet Pharmacol Ther. (1996) 19:466-74. doi: 10.1111/j.1365-2885.1996.tb00084.x

40. Mennillo E, Arukwe A, Monni G, Meucci V, Intorre L, Preti C. Ecotoxicological properties of ketoprofen and the $\mathrm{S}(+)$-enantiomer (dexketoprofen): Bioassays in freshwater model species and biomarkers in fish PLHC-1 cell line. Environ Toxicol Chem. (2018) 37:201-12. doi: 10.1002/etc.3943

41. Heavner JE, Cooper DM. Pharmacology of Analgesics. In: Fish RE, Brown MJ, Danneman PJ, Karas AZ, editors. Anesthesia and Analgesia in Laboratory 
Animals. American College of Laboratory Medicine Series. London: Elsevier Inc. (2008). p. 97-123. doi: 10.1016/B978-012373898-1.50008-5

42. Landoni MF, Lees P. Pharmacokinetics and pharmacodynamics of ketoprofen enantiomers in the horse. J Vet Pharmacol Ther. (1996) 19:466-74.

43. Navarro RD, Franca RP, Paludo GR, Wlademir Y, Bizarro S, da Silva RF, et al. Physiological and hematological responses of Nile tilapia (Oreochromis Niloticus) to different anesthetics during simulated transport conditions. Acta Sci Agron. (2016) 38:301-6. doi: 10.4025/actascitechnol.v38i 3.28377

44. Rucinque DS, Polo G, Borbón J, Mantilla JFG. Anesthetic use of eugenol and benzocaine in red tilapia (Oreochromis sp.). Revista Colombiana de Ciencias Pecuarias. (2017) 30:60-6. doi: 10.17533/udea.rccp.v30n1a07

45. Wagner GN, Singer TD, McKinley RS. The ability of clove oil and MS-222 to minimize handling stress in rainbow trout (Oncorhynchus mykiss Walbaum). Aquac Res. (2003) 34:1139-46. doi: 10.1046/j.1365-2109.2003.00916.x

46. Sloman KA, Bouyoucos IA, Brooks EJ, Sneddon LU. Ethical considerations in fish research. J Fish Biol. (2018) 94:556-77. doi: 10.1111/jfb.13946

47. Zahl IH, Samuelsen O, Kiessling A. Anaesthesia of farmed fish: implications for welfare. Fish Physiol Biochem. (2012) 38:201-18. doi: 10.1007/s10695-011-9565-1

48. Horsberg TE. Experimental methods for pharmacokinetic studies in salmonids. Ann Rev Fish Dis. (1994) 4:345-58. doi: 10.1016/0959-8030(94)90034-5

49. Kiessling A, Johansson D, Zahl IH, Samuelsen OB. Pharmacokinetics, plasma cortisol and effectiveness of benzocaine, MS-222 and isoeugenol measured in individual dorsal aorta-cannulated Atlantic salmon (Salmo salar) following bath administration. Aquaculture. (2009) 286:301-8. doi: 10.1016/j.aquaculture.2008.09.037

50. Popovic NT, Strunjak-Perovic I, Coz-Rakovac R, Barisic J, Jadan M, Berakovic AP, et al. Tricaine methane-sulfonate (MS-222) application in fish anaesthesia. J Appl Ichthyol. (2012) 28:1-12.

51. Pasnik DJ, Evans JJ, Klesius PH. Influence of tricaine methanesulfonate on Streptococcus agalactiae vaccination of Nile tilapia (Oreochromis niloticus). Vet Res. (2008) 2:28-33.
52. Cooke SJ, Brownscombe JW, Raby GD, Broell F, Hinch SG, Clark TD, et al. Remote bioenergetics measurements in wild fish: opportunities and challenges. Comp Biochem Physiol A Mol Integr Physiol. (2016) 202:23-37. doi: 10.1016/j.cbpa.2016.03.022

53. Smith DA, Smith SA, Holladay SD. Effect of previous exposure to tricaine methanesulfonate on time to anesthesia in hybrid tilapias. J Aquat Anim Health. (2011) 11:183-6. doi: 10.1577/1548-8667(1999)011\&lt;0183:EOPETT\&gt;2.0.CO;2

54. Akhtar N. Anesthesia, abdominal surgery, and efficacy of ovariectomy and subsequent androgen treatments in inducement of sex reversal in Tilapia Nilotica (Ph.D. dissertation). Auburn University, Auburn, AL, United States (1984).

55. Newsby NC, Mendoca PC, Gamperl K, Stevens ED. Pharmacokinetics of morphine in fish: pharmacokinetics of morphine in fish: winter flounder (Pseudopleuronectes americanus) and seawater-acclimated rainbow trout (Oncorhynchus mykiss). Comp Biochem Physiol C Toxicol Pharmacol. (2006) 143:275-83. doi: 10.1016/j.cbpc.2006. 03.003

56. Antonia K, Alevizou A, Tesseromatis C. Stress can affect drug pharmacokinetics via serum/tissues protein binding and blood flow rate alterations. Eur J Drug Metab Pharmacokinet. (2011) 37:1-7. doi: 10.1007/s13318-011-0077-2

Conflict of Interest: The authors declare that the research was conducted in the absence of any commercial or financial relationships that could be construed as a potential conflict of interest.

Copyright $\odot 2020$ Greene, Mylniczenko, Storms, Burns, Lewbart, Byrd and Papich. This is an open-access article distributed under the terms of the Creative Commons Attribution License (CC BY). The use, distribution or reproduction in other forums is permitted, provided the original author(s) and the copyright owner(s) are credited and that the original publication in this journal is cited, in accordance with accepted academic practice. No use, distribution or reproduction is permitted which does not comply with these terms. 